\title{
Assessment of recharge potential zones for groundwater development and management using geospatial and MCDA technologies in semiarid region of Western India
}

\author{
Ajaykumar Krushna Kadam ${ }^{1}$ (I) $\cdot$ Bhavana N. Umrikar² $\cdot$ R. N. Sankhua ${ }^{3}$
}

Received: 21 September 2019 / Accepted: 21 January 2020 / Published online: 31 January 2020

(c) Springer Nature Switzerland AG 2020

\begin{abstract}
Groundwater recharge potential (GWRP) plays a vital role as it directly or indirectly supports domestic, agriculture and industrial activities by infiltrating the rainwater. The present paper touches upon the methodology delineating groundwater recharge potential zones by applying geospatial and multi-criteria decision analysis (MCDA) to the derived thematic layers based on significant influence of occurrence of groundwater in semiarid watershed of Western India. The satellite imageries and other ancillary data were utilized to generate various thematic layers, viz. slope, geology, drainage density, surface run off, geomorphology, land use/land cover soil and vadose zone. The outcome of study shows that about $24.69 \%$ is having high GWRP and $24.17 \%$ of the area is moderate for recharge of groundwater, while the low and poor ground water recharges potential area is about $44.34 \%$ and $6.80 \%$ of total area, respectively. The validation of the study was done by overlaying point data groundwater well yield on the output final map; it shows good correlation with result. Also, the surplus water availability was calculated based on vadose calculation according to CGWB method; it shows 17.12 MCM vadose region having artificial recharge of $22.77 \mathrm{MCM}$. The total recharge is about $117.41 \mathrm{MCM}$, about $30 \%$ of the total runoff, i.e. $35.22 \mathrm{MCM}$ is considered as surplus monsoon runoff available for artificial recharge. The result shows that the use of remote sensing, geospatial and MCDA technologies are promising and efficiently recognize the suitable regions for groundwater recharge over other conventional techniques.
\end{abstract}

Keywords Groundwater recharge potential $\cdot$ MCDA $\cdot$ Semiarid watershed $\cdot$ Western India

\section{Introduction}

Groundwater source is generally safe and prime source of drinking water due to less pollution as compared to the surface water [1-3]. The increasing inhabitants, farming activities and rapid industrialization have led to continuous extraction, depletion and degradation of groundwater. Currently, $85 \%$ of rural population in India fulfils the drinking and domestic water demands from groundwater $[4,5]$. The recharge of groundwater occurs when rainfall or snowmelt water infiltrates into the aquifer [6,
7]. The occurrence and movement of groundwater are determined by physical edifices, topographic condition, lithological difference, gradient, soil, drainage form and climate [8-10]. Hence, it is necessary to consider all these factors, to understand groundwater recharge potential of an area. The efficient groundwater recharge quantification requires accurate scientific measures and modern techniques $[11,12]$. The traditional in situ investigations of groundwater recharge potential are time-consuming and expensive [13-15]. In recent years, with the improvement of modern spatial techniques for hydrological applications,

Ajaykumar Krushna Kadam, kadamajaykumar1@gmail.com; Bhavana N. Umrikar, bnumrikar@gmail.com; R. N. Sankhua, sankhua12@yahoo.com | 1 Department of Environmental Science, Savitribai Phule Pune University, Pune, India. ${ }^{2}$ Department of Geology, Savitribai Phule Pune University, Pune, India. ${ }^{3}$ Central Water Commission, New Delhi, India. 
the mapping of groundwater recharge potential zones is faster and more cost-effective [16]. Many researchers across the world have carried out groundwater potentiality studies using integrated remote sensing and GIS technique [17-22]. An accurate groundwater recharge potential zones mapping in representative semiarid basin can help in resourceful management of this vital source and decrease the groundwater susceptibility in the region $[12,23]$. Therefore, an effort has been made in this study to define groundwater recharge potential zones of Shivganga watershed using MCDA, in preparation of groundwater development plan.

\section{Study area}

The Shivganga watershed is situated at lower altitude of Western Ghats and has an aerial extent of about $177 \mathrm{~km}^{2}$. The study area lies between longitudes $73^{\circ} 44^{\prime} 1.131^{\prime \prime}$ E and $73^{\circ} 56^{\prime} 17.941^{\prime \prime} \mathrm{E}$ and latitude $18^{\circ} 13^{\prime} 36.059^{\prime \prime} \mathrm{N}$ to $18^{\circ} 24^{\prime} 7.466^{\prime \prime} \mathrm{N}$ (Fig. 1). It is represented in the Survey of India (SOI) topographic sheet numbers $47 \mathrm{~F} / 15$ and $47 \mathrm{~F} / 16$ on 1:50,000 scale. The study area is categorized into four sub-watersheds based on the drainage divided. The area receives average rainwater of $964 \mathrm{~mm}$ from south-westerly monsoon between June and September. The climate of the area is semiarid having average temperature $36^{\circ} \mathrm{C}$ during summer and about $18^{\circ} \mathrm{C}$ during winter. Shivganga River originates at Sinhagad fort foothills and further confluence with Gunjawani River near Mohari Budrukh village. The high elevation patch is situated in western part $(1264 \mathrm{~m})$ and lower elevation $(590 \mathrm{~m})$ is in easternmost portion of region $[24,25]$.

\section{Methodology}

The GWR potential has been assessed for quantification of groundwater recharge in study area. Figure 2 portrays the technique of implemented and procedures adopted for groundwater recharge potential mapping in the study area. The study area base map, watershed and sub-watershed maps were demarcated from topographic map and natural drain lines. Strahler (1957) stream ordering scheme was used for giving orders to natural drain lines. Study area was divided into four sub-watersheds: SW1, SW2, SW3 and SW4 (Fig. 1), which future used for calculation of recharge potential area. The drainage density (Dd) map was derived from the natural drain lines in ArcGIS platform. The contour map combined with ASTER data was used to generate the elevation map, which further used for deriving slope and validated with field triangulation points for better accuracy. The resource maps with ground-based data were used for preparation of geomorphology, geology and soil maps of the study area. The geomorphology map was procured from the National Atlas and Thematic Mapping Organisation (NATMO), which is further updated using satellite image. The geology map was purchased
Fig. 1 Location map of Shivganga basin

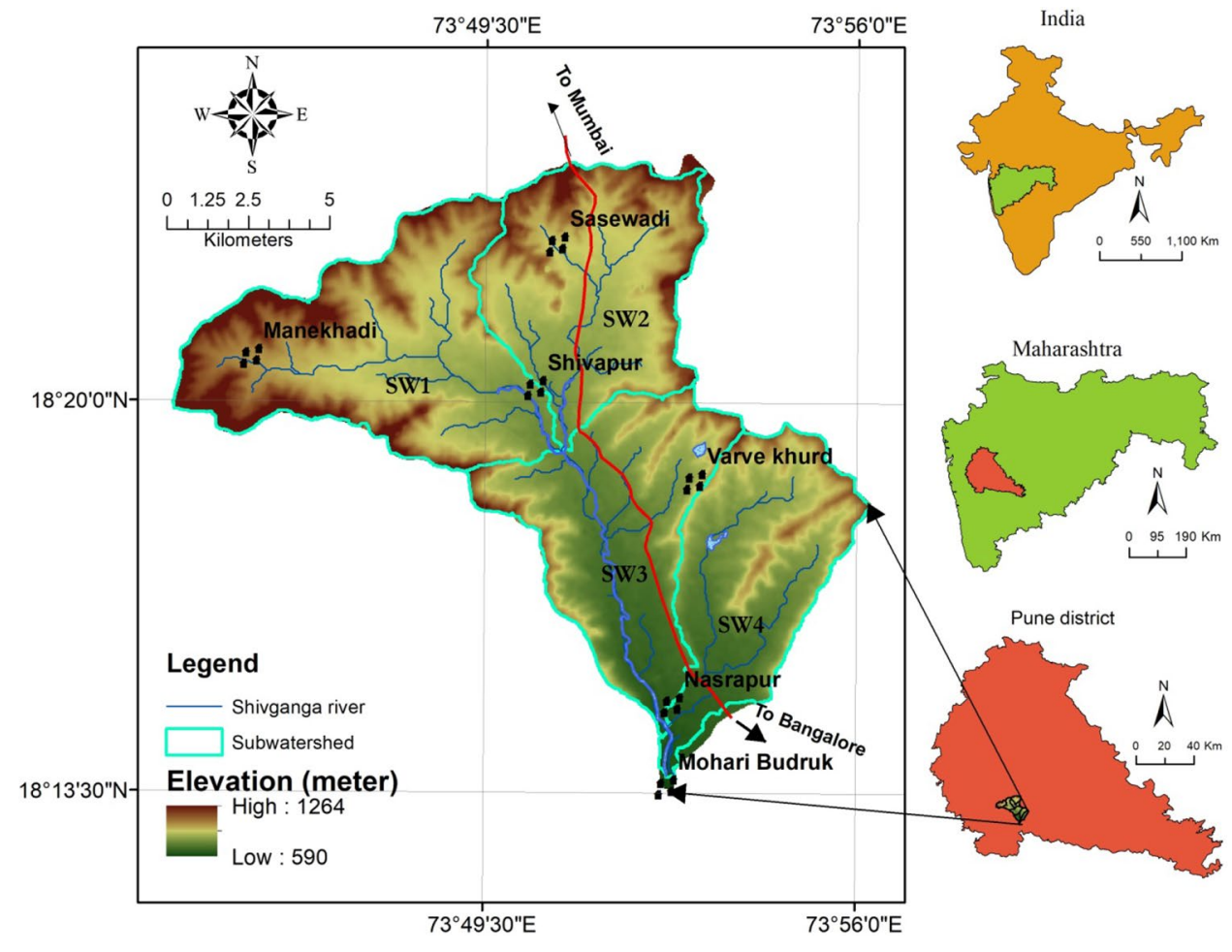




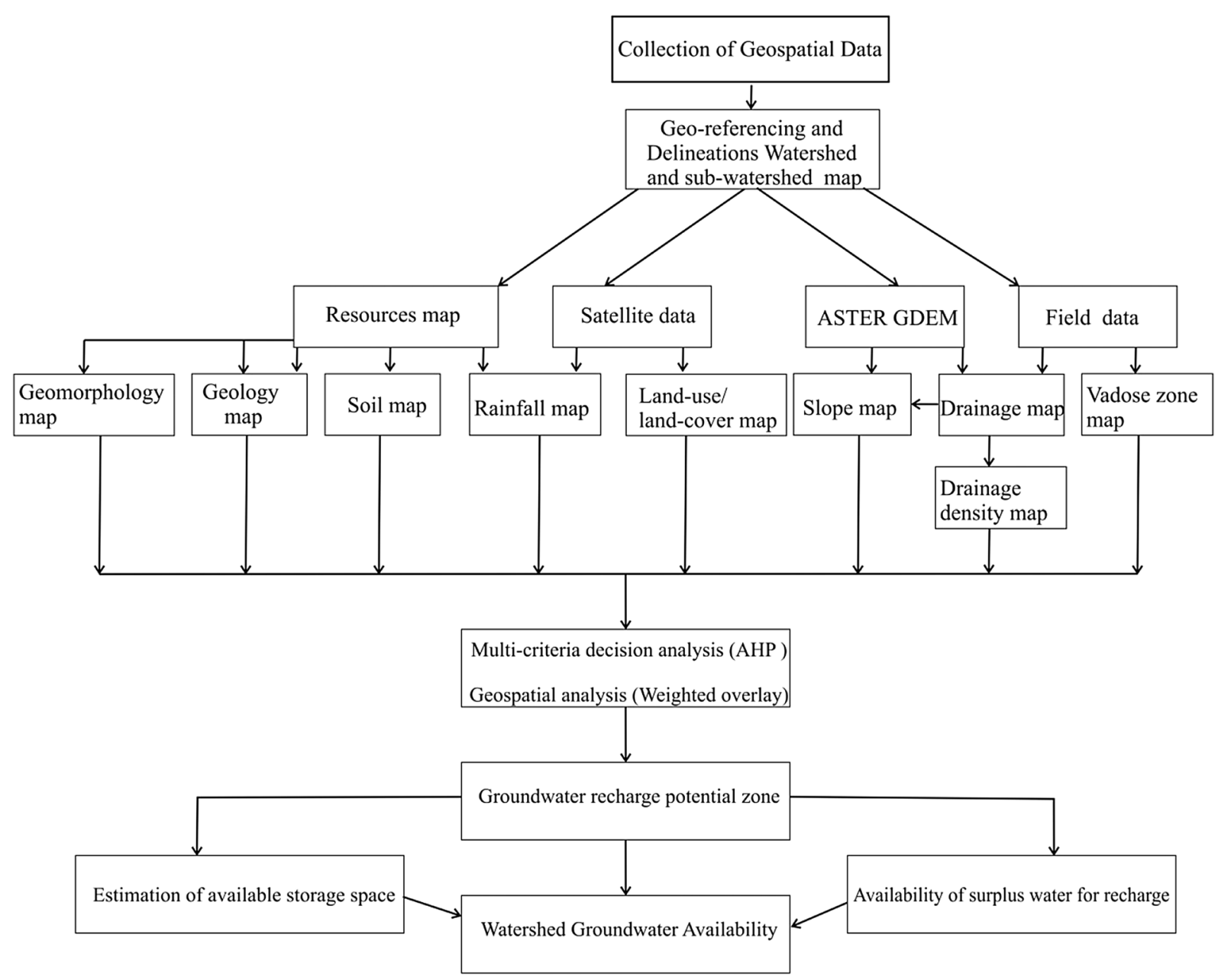

Fig. 2 Flowchart for delineating the groundwater recharge potential zone

from the Geological Survey of India (GSI), which is further updated using satellite image. Soil map was purchased from National Bureau of Soil Survey and Land Use Planning (NBSS \& LUP) Nagpur. The land use/land cover map was prepared from LANDSAT image and updated with corrected with satellite imageries available on Google and Bhuvan websites. The rainfall map was prepared by Thiessen polygon method in GIS environment and updated with remote sensing-based Tropical Rainfall Measuring Mission (TRMM) monthly rainfall data from NASA for preparation spatial variation in rainfall of study area. The vadose zone map was prepared by the change in groundwater level data of pre- and post-monsoon data. UTM projection and WGS-84 co-ordinate system were assigned to all thematic layers with $30 \mathrm{~m}$ pixel resolution and converted to raster format for performing weighted overlay analysis using GIS software. Multi-criteria decision analysis (MCDA) method such as AHP is used to delimit the weightage of feature layer to eliminate the biasness in the output map. Based on MCDA analysis, resultant weightage was given to the thematic layer and suitable ranking was allotted to each class of respective theme [24, 25]. The rank was assigned in the scale of 1-5, where 5 represents the good recharge potential, while the 1 represents poor recharge potential. The recharge potential was classified into poor, low, moderate and high classes.

Based on above identified and groundwater available recharge zone identified using CGWB-based groundwater vadose zone method, the watershed available recharge is calculated as sub-watershed basis. Based on that, the availability surplus water for recharge was calculated, which helps in calculating watershed groundwater availability.

\section{Result and discussion}

\subsection{Geomorphology}

Geomorphological investigations throw light on topography, landforms and drainage network. Various processes 
such as weathering, erosion and deposition have produced different landform in upstream and downstream sections in the area. The various geomorphic units of the basin have been divided into weathered shallow or weathered terrain, moderately dissected or slightly dissected terrain, mesa/buttes, highly dissected terrain and escarpment (Fig. 3). Among all these, the weathered shallow or weathered terrain that is best for recharge is given the rank 5 , while moderately dissected or slightly dissected terrain that is good for groundwater recharge is assigned the value 4 . The highly dissected area generates high surface runoff due to exposure of basaltic rock; poor soil cover, steep slopes and scares vegetation hence possess poor groundwater recharge potential is assign the rank 1.

\subsection{Drainage density}

The $\mathrm{Dd}$ is the fraction of stream length per kilometre square of the area [26]. It indicates the ability of area to recharge the precipitation. It is the function of geology, geomorphology, rainfall, gradient, land utilization pattern and infiltration capacity of vadose zone [27, 28]. Soil and bedrock physiognomies disturb the overland flow in the study area. Drainage density enables a calculable investigation of the typical distance of rivulet conduits elongating the complete part of the watershed area. The resultant map shows the low density area present near main stream at central part of basin increasing towards peripheral part of basin. The drainage density is classified into excellent to 'very good' $\left(0-0.467 \mathrm{~km} / \mathrm{km}^{2}\right)$, 'very good to good' $\left(0.467-1.236 \mathrm{~km} / \mathrm{km}^{2}\right)$, 'good to moderate' (1.236-1.841 km/km²),'moderate to poor'(1.841-2.46 km/ $\left.\mathrm{km}^{2}\right)$ and 'poor to very poor' $\left(>2.46 \mathrm{~km} / \mathrm{km}^{2}\right)$ as shown in Fig. 4. Higher density category has been considered as low to poor recharge potential area, showing very less scope for permeability of bedrock, which is assigned the value 1 , whereas the lower density area that offers the higher possibility of groundwater recharge is given the value 5 .

\subsection{Slope}

Slope affects the rainwater to infiltrate and overflow and therefore acts as an important parameter for groundwater recharge potential studies [29]. The high slope area results into quick runoff and low retaining period to infiltrate water and thus considered as 'poor' for groundwater recharge, while table land having high water for longer retention time, thus, shows high porosity and permeability rate. The slope map is generated from digital elevation model and reclassified in five slope classes. Figure 5 shows that slope alters from 0 to $25 \%$. The high gradient area established in the periphery of the study area, showing less percolation, which is assigned the value 1 , while flat terrain having $0-5 \%$ slope occupies majority of the area. This major part of the area was observed in flat terrain

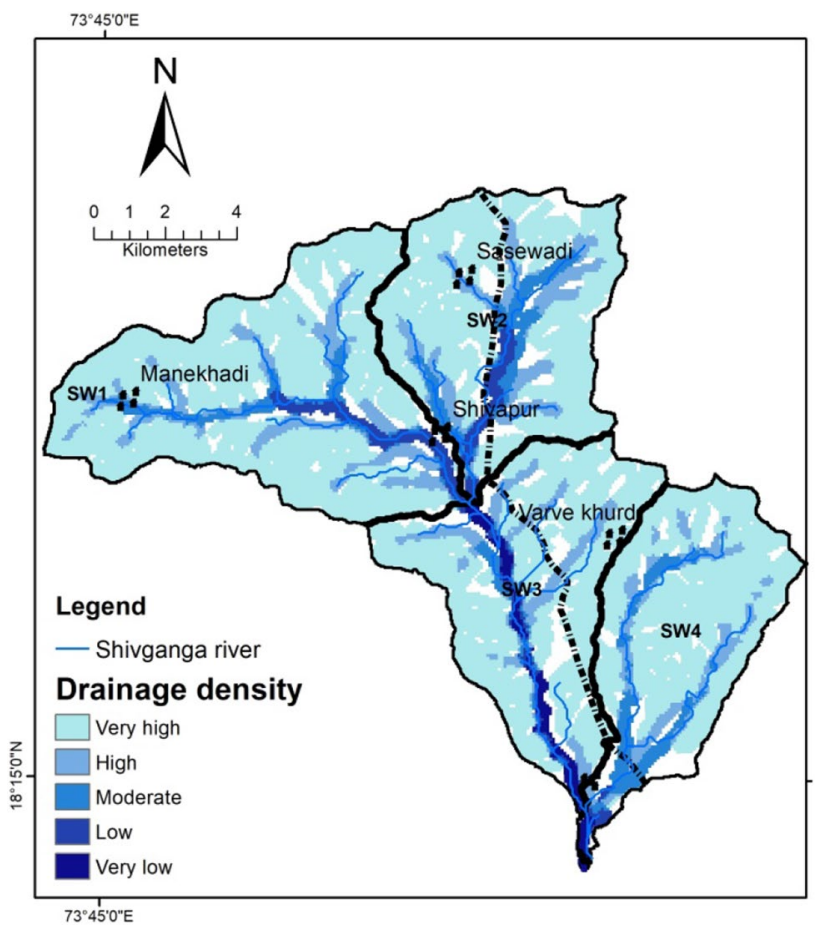

Fig. 4 Drainage density map

Fig. 3 Geomorphology map 


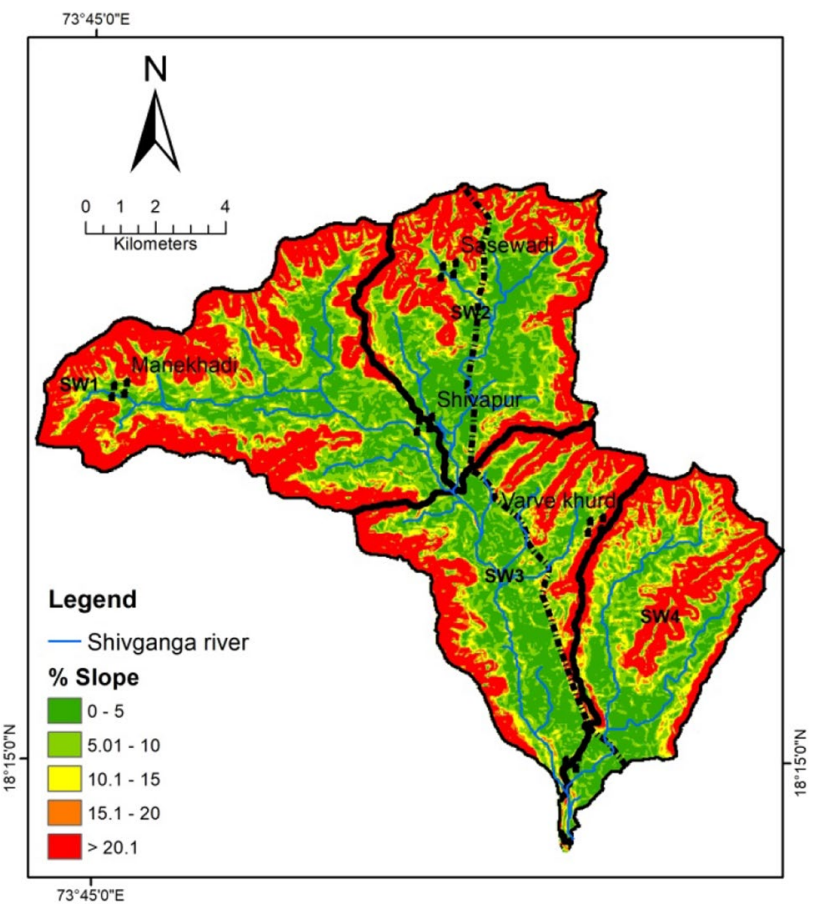

Fig. 5 Slope variation map of study area

covering almost $40 \%$ of the region; hence, the region is 'good' for groundwater recharge which is assigned the value 5 .

\subsection{Rainfall}

Rainfall is directly related to groundwater recharge potential and determines the availability of water to percolate into the subsurface. The rainfall occurs in the months from June to September. The area also experiences showers from the retrieving monsoon in the months of October and November. The average annual rainfall is around $1016 \mathrm{~mm}$ recorded from 1950 to 2010. The spatial distribution of rainfall is obtained from TRMM data which reveals that the rainfall increases towards the northwest part of the study area (Fig. 6). Then, the TRMM precipitation grid-based data were added around by 'grid adds' and 'grid mean' tool of GIS to prepared annual average rainfall map. The rainfall area with values less than $900 \mathrm{~mm}$ will be assigned the rank 1 , while the north-western part having rainfall more than $1100 \mathrm{~mm}$ is given the rank 5 .

\subsection{Geology}

The Deccan Volcanic Province having flows belonging to Sahyadri Group particularly Purandargarh and Diveghat formation occupies the study area. This mappable flow is a sub-unit made up of uninterrupted eruption of lava and

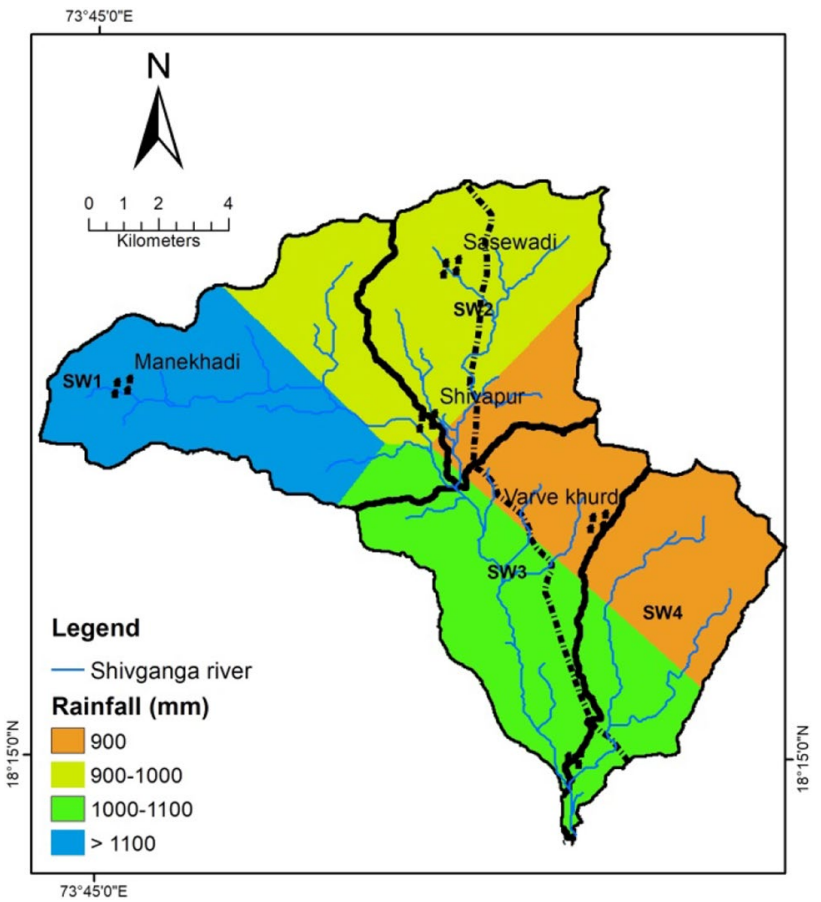

Fig. 6 Rainfall variation map of study area

the product of single lava. Flow fields are identified on the basis of field relation and morphology. These are generally the eruptions that cover a huge area and contain several lava flow units. The basalt lava flows visible in the region found equally compound pahoehoe and a'a flow forms. There are certain flows showing mixed typescripts. These are of the intermediate nature and display change from pahoehoe to a'a flows. The flows are roughly $400 \mathrm{~m}$ thick that includes simple type basalt flows with a few compound flows. The top of Purandargarh formation is marked by $20-25-m$-thick megacrystic flow covering bulky plagioclase phenocrysts. Diveghat formation vitrines compound pahoehoe flow with main vesicles covers huge part of the basin area (Fig. 7).

\subsection{Soil}

Soil plays a supportive vital role in the recharge of groundwater in that area $[3,30]$. As per the soil survey map and field study, area is characterized as sandy loam, loam clay and clay types (Fig. 8) [25]. Most of the study regions mainly have HSG-B soil type (48\%) and HSG-C soil type (43\%). HSG-B soil has good amount of rainwater infiltration due to high perviousness and penetrability; hence, it has been assigned highest priority is given the rank 5 . HSG-D soil is compacted and impermeable; hence, given low priority ranks 1 . 


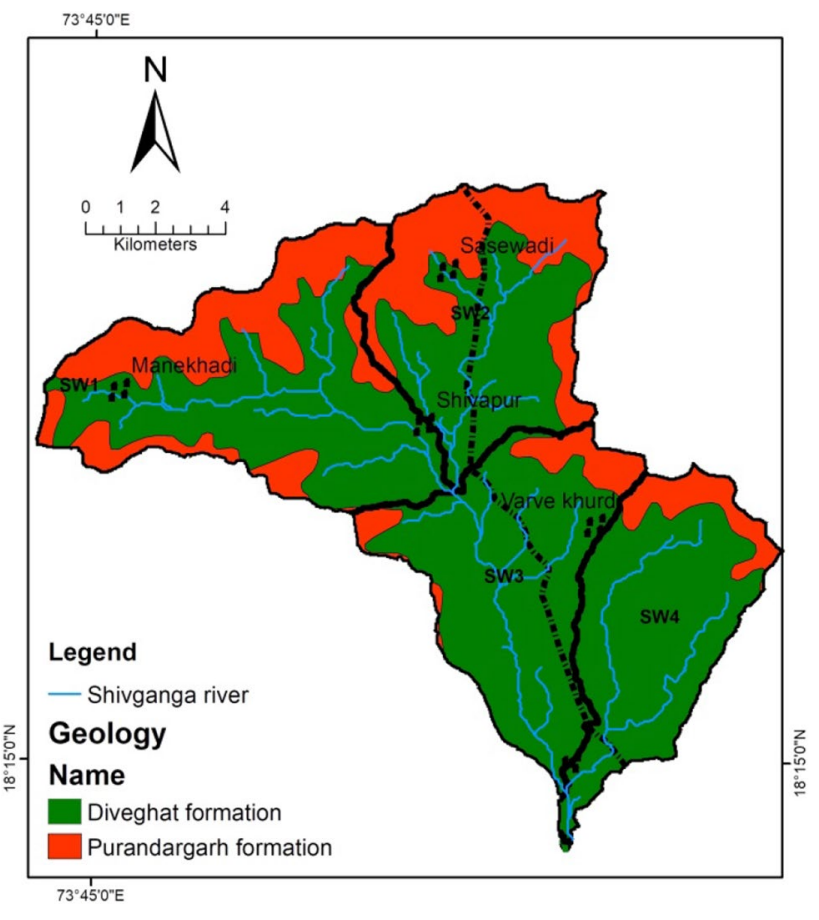

Fig. 7 Geology of Shivganga River basin

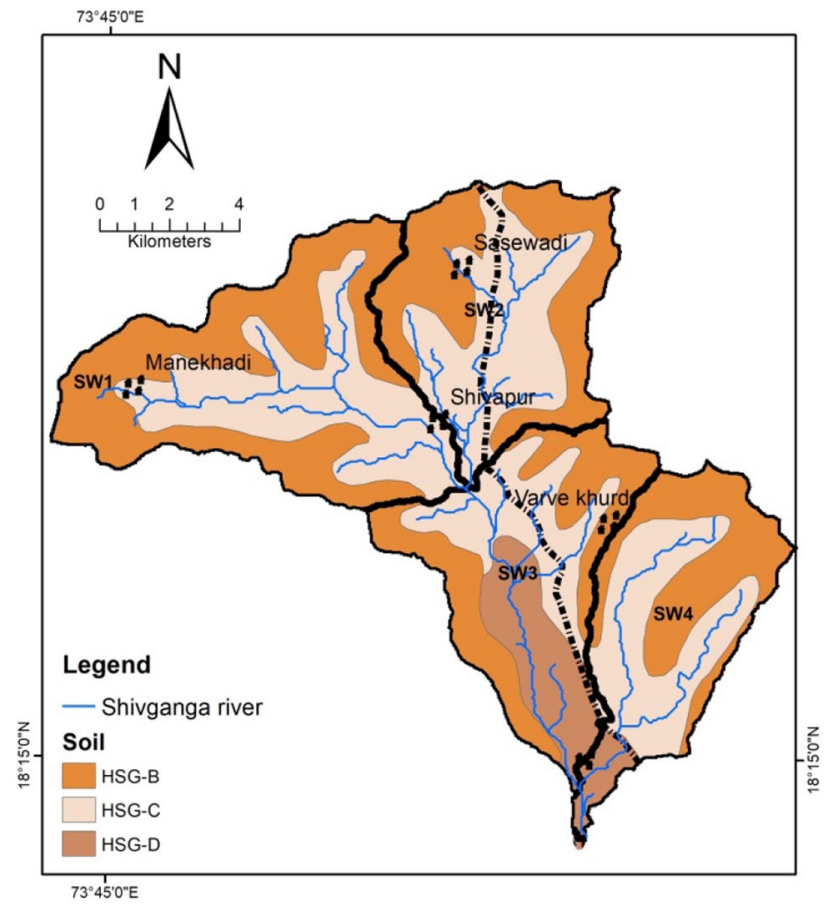

Fig. 8 Soil map of Shivganga River basin

\subsection{Land use class}

Land use is an important indicator of hydrogeological changes in water cycle as it affects the overland flow, evapotranspiration, infiltration and restores aquifer system [31]. LANDSAT ETM+ images have been used to prepare the spatial distribution of land use classes of the study area. The main land utilization class type comprises of agriculture, waste, forest/vegetation, built-up land and water bodies (Fig. 9). The land covered with forest/vegetation and agriculture land creates low overland flow [32], therefore considered as 'good' for GWR, and hence ranked 5. In contrast, in built-up land percolates less of water, hence considered as poor groundwater recharge potential sites, are given the rank 1 .

\subsection{Vadose zone}

The vadose zone is the section of the rock material above the groundwater table. Hydrologically, this zone is crucial in proportionating the rainwater in subsurface infiltration and surface runoff. The soil water belt of vadose zone draws attention of agriculturists and soil scientists as the characteristics of this zone governs support to crops. The thickness of vadose zone increases along linear structures as well as reaches to valley floor in the study area as confirmed through the well inventory conducted during field work. The vadose zone thickness is categorized

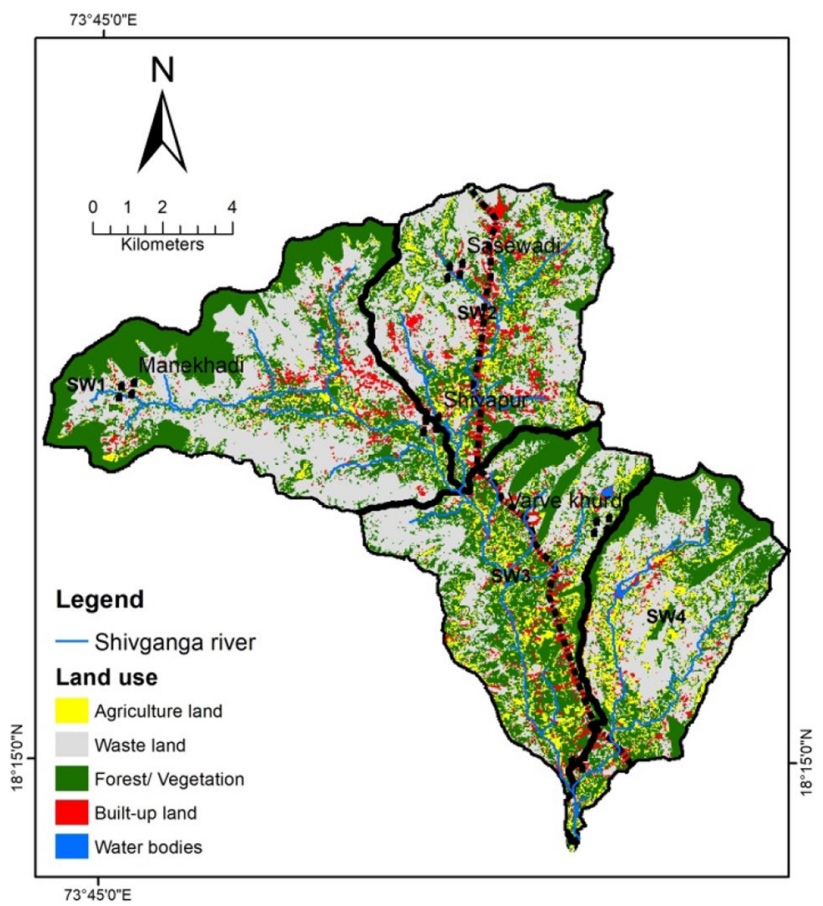

Fig. 9 Land use map 


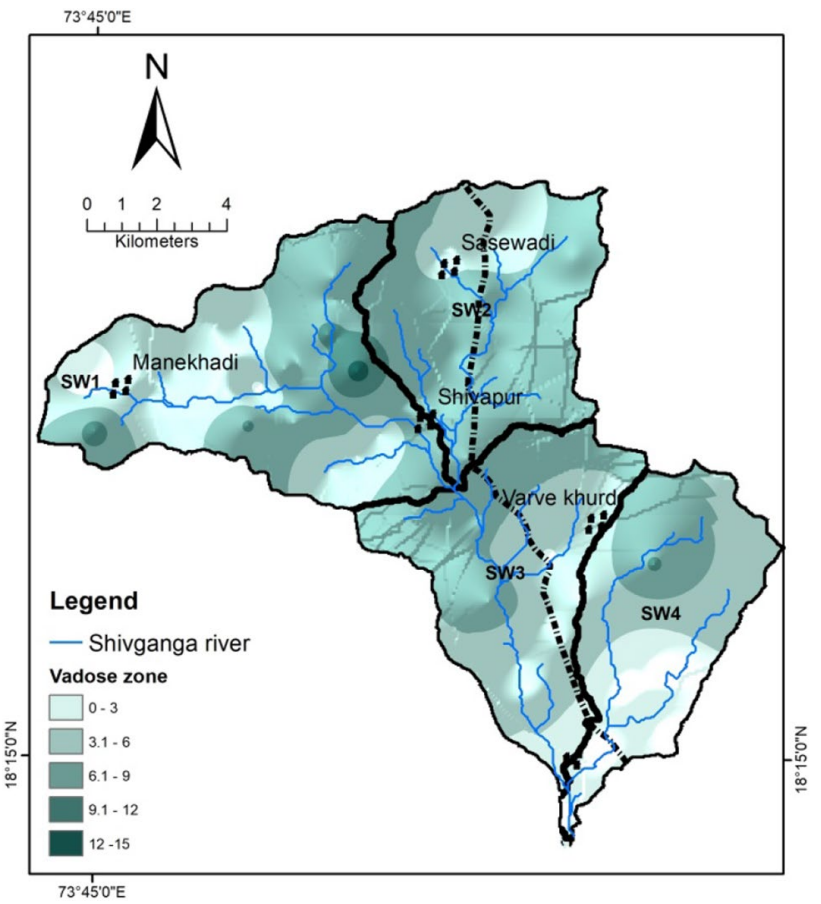

Fig. 10 Vadose zone map

into $0-3,3-6,6-9,9-12$ and $>12 \mathrm{~m}$ below the ground (Fig. 10). The vadose zone thickness $0-3$ shows less potential for groundwater recharge which is given the rank 1 and $>12 \mathrm{~m}$ below the ground is having high potential of recharge which is assigned the rank 5 .

\section{Generation of pair-wise comparison matrices through AHP}

Multi-criteria analysis technique such as AHP is used to define the weightage of thematic layer to remove the biasness in the resultant map. The AHP technique provides the comparative assessment between the parametric layers using pair-wise matrix that is further used for deriving the consistency of the assumption. The relative importance of parameter within themselves is given by referring the scale of 1-9 digits, where the 1 value is having equal importance for both comparative parameters while the 9 is having extreme important of one parameter over other (Table 1).

The random index (RI) value is a function of the number parameter $(n)$ taken into consideration for comparison matrix. The random index values are given in table below (Table 2).

The last step in AHP procedure is to find consistency of resultant weight as well as the reliability of assumption. The consistency ratio is consistency index divided by random index value.

Based on AHP analysis for groundwater recharge zone identification, the $C R$ value got is 0.097 , which is below 0.10 , i.e. $10 \%$, so the weightages assigned to themes are accepted. The AHP shows that the rainfall (20.34\%) is having highest weight, followed by the vadose zone, while the drainage density is having lowest weight $(2.97 \%)$ as shown in Table 3. These weights were further used for identification of groundwater recharge potential areas as a final output map using weighted overlay analysis in GIS environment.

\section{Weighted overlay analysis for recharge zone identification}

The weights obtained using AHP were assigned to the thematic layer, while the ranks were given to the feature class of each thematic layer (Table 4).

The high recharge potential zone represented mainly plateau weathered geomorphology, agriculture as major land use, sandy clay type of soil with 9-15 m vadose zone thickness having slope less than $5 \%$, hence offering higher resident time to rainwater for infiltration and increased the recharge to aquifer. The moderate recharge potential zone occurs in area having moderate slope, moderately dissected plateau with fallow/wasteland having loamy clay soil type showing mainly vadose zone thickness between 6 and $12 \mathrm{~m}$ (Fig. 11).

The low recharge is associated with the upstream part occupied by Diveghat formation having moderate to high drainage density with wasteland with sparse vegetation

Table 1 Saaty's 1-9 scale of relative importance

\begin{tabular}{llllllllll}
\hline Scale & 1 & 2 & 3 & 4 & 5 & 6 & 7 & 8 & 9 \\
\hline Importance & \multirow{2}{*}{ Equal } & Weak & Moderate & Moderate plus & Strong & Strong plus & Very strong & Very, very strong & Extreme \\
\hline
\end{tabular}

Table 2 Different RI values (Saaty 2008)

\begin{tabular}{llllllllll}
\hline$n$ & 1 & 2 & 3 & 4 & 5 & 6 & 7 & 8 & 9 \\
\hline $\mathrm{RI}$ & 0 & 0 & 0.58 & 0.9 & 1.12 & 1.24 & 1.32 & 1.41 & 1.46 \\
\hline
\end{tabular}


Table 3 Pairwise comparison matrix and final weights obtained for thematic layer

\begin{tabular}{llllllllll}
\hline Parameter & Geomorphology & Geology & LULC & DD & Soil & Vadose zone & Slope & Rainfall & \% weight \\
\hline Geomorphology & 1.000 & 0.500 & 0.333 & 5.000 & 5.000 & 0.500 & 1.000 & 0.143 & 11.14 \\
Geology & 2.000 & 1.000 & 0.250 & 4.000 & 1.000 & 0.500 & 0.500 & 3.000 & 12.52 \\
LULC & 3.000 & 4.000 & 1.000 & 5.000 & 2.000 & 0.333 & 3.000 & 0.250 & 16.59 \\
Drainage density & 0.200 & 0.250 & 0.200 & 1.000 & 0.333 & 0.250 & 0.200 & 0.333 & 2.97 \\
Soil & 0.200 & 1.000 & 0.500 & 3.000 & 1.000 & 0.333 & 2.000 & 1.000 & 8.54 \\
Vadose zone & 2.000 & 0.500 & 3.000 & 4.000 & 3.000 & 1.000 & 3.000 & 2.000 & 19.33 \\
Slope & 1.000 & 2.000 & 0.333 & 5.000 & 0.500 & 0.333 & 1.000 & 0.200 & 8.56 \\
Rainfall & 7.000 & 0.330 & 4.000 & 3.000 & 1.000 & 0.500 & 5.000 & 1.000 & 20.34 \\
\hline
\end{tabular}

Table 4 Detailed weights and relative weights of various thematic layers

\begin{tabular}{|c|c|c|c|c|}
\hline Parameter & Categories & Rank & AHP \% weights & Final AHP weight \\
\hline \multirow[t]{2}{*}{ Geology } & Diveghat formation & 3 & 12.52 & $12.52 \times 3=37.65$ \\
\hline & Purandargarh formation & 2 & & 12.52 \\
\hline \multirow[t]{8}{*}{ Geomorphology } & Butte & 1 & 11.14 & 11.14 \\
\hline & Escarpment & 1 & & 11.14 \\
\hline & Mesa & 1 & & 11.14 \\
\hline & Plateau highly dissected & 1 & & 11.14 \\
\hline & Plateau moderately dissected & 3 & & 33.42 \\
\hline & Plateau shallow weathered & 4 & & 44.56 \\
\hline & Plateau slightly dissected & 2 & & 22.28 \\
\hline & Plateau weathered & 5 & & 55.70 \\
\hline \multirow[t]{5}{*}{ Land use/land cover } & Wasteland & 2 & 16.59 & 33.18 \\
\hline & Built-up land & 1 & & 16.59 \\
\hline & Vegetation/forest & 3 & & 49.77 \\
\hline & Agriculture land & 5 & & 82.95 \\
\hline & Water bodies & 4 & & 66.36 \\
\hline \multirow[t]{5}{*}{ Drainage density } & Very high & 1 & 2.97 & 2.97 \\
\hline & High & 1 & & 2.97 \\
\hline & Moderate & 2 & & 5.94 \\
\hline & Low & 3 & & 8.91 \\
\hline & Very low & 4 & & 11.88 \\
\hline \multirow[t]{3}{*}{ Soil } & HSG-B & 4 & 8.54 & 34.16 \\
\hline & HSG-C & 2 & & 17.08 \\
\hline & HSG-D & 1 & & 8.54 \\
\hline \multirow[t]{5}{*}{ Vadose zone (m) } & $0.0-3.0$ & 1 & 19.33 & 19.33 \\
\hline & $3.1-6.0$ & 2 & & 38.66 \\
\hline & $6.1-9.0$ & 3 & & 57.99 \\
\hline & $9.1-12.0$ & 4 & & 77.32 \\
\hline & $>12$ & 5 & & 96.65 \\
\hline \multirow[t]{5}{*}{ Slope } & $0-5 \%$ & 5 & 8.56 & 42.80 \\
\hline & $5-10 \%$ & 4 & & 34.24 \\
\hline & $10-15 \%$ & 3 & & 25.68 \\
\hline & $15-20 \%$ & 2 & & 17.12 \\
\hline & $>20 \%$ & 1 & & 8.56 \\
\hline \multirow[t]{4}{*}{ Rainfall } & $<900$ & 1 & 20.34 & 20.34 \\
\hline & $900-1000$ & 2 & & 40.68 \\
\hline & $1000-1100 \mathrm{~mm}$ & 3 & & 61.02 \\
\hline & $>1100 \mathrm{~mm}$ & 4 & & 81.36 \\
\hline
\end{tabular}




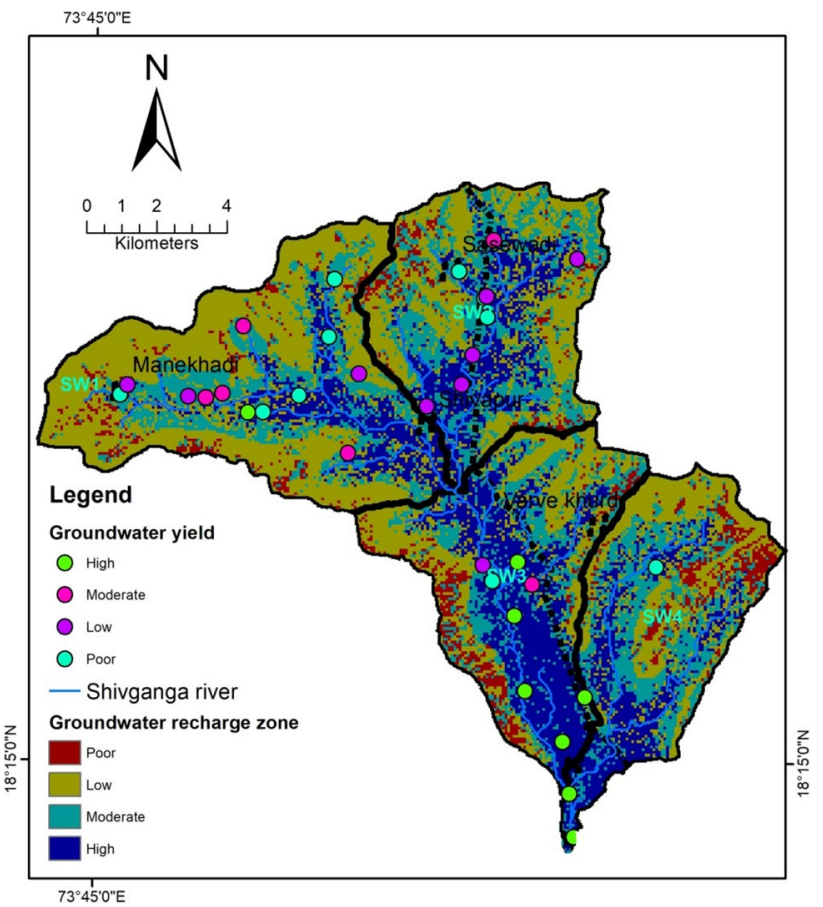

Fig. 11 Groundwater recharge potential zone map of study area

resulting into less resident time of water over the surface. The poor recharge potential zone shows basaltic flows mainly from Purandargarh formation with very high drainage density and steep slopes covering mesa and buttes. The poor recharge potential area mainly has the barren land with very less developed vadose zone, i.e. up to $4 \mathrm{~m}$.

\section{Estimation of available storage space}

The overall dimensions of vadose zone unsaturated are assessed, and actual volume of water essential to recharge the subsurface has been considered by multiplying with average specific yield of study area, i.e. 0.02\% [33]. Typical formularies have been used in this method to estimate the volume of rainwater essential to recharge the unsaturated zone (Table 5). Apart from the recharge due to precipitation, in present study area approximately $17.12 \mathrm{M} \mathrm{m} 3$ recharge potential zone is available for artificial recharge.

The next step is the calculation of surface water availability by analysing the monsoonal precipitation pattern for groundwater recharge. As per the CGWB norms, $75 \%$ of water is recharged by the rainwater harvesting structures [34]. Thus, surface water requirement $=$ storage space $\times 1.33$ (A reciprocal of $75 \%$ efficiency). In the river basin, around $17.12 \mathrm{MCM}$ is the available volume for artificial recharge (Table 5).

So, the water essential for artificial recharge $=17.12$ $\times 1.33=22.77 \mathrm{MCM}$.

The normal average monsoon rainfall for last 50 years is $945 \mathrm{~mm}$ (IMD). The percentage of runoff to rainfall is given in Table 6. The total runoff generated from study area is about $117.41 \mathrm{MCM}$. The saturated area could store 117.41 MCM, whereas $30 \%$ of the total runoff $(35.22$ $\mathrm{MCM}$ ) is considered as surplus monsoon runoff available for arresting in the form of artificial recharge.

The availability study shows that sub-watershed SW4 receives less rainfall $(900 \mathrm{~mm})$, hence less surplus water

Table 5 Estimation of subsurface recharge capacity

\begin{tabular}{|c|c|c|c|c|c|}
\hline WL & Area $\left(\mathrm{km}^{2}\right)$ & $\begin{array}{l}\text { Depth to water level (post-mon- } \\
\text { soon) below cut-off level (m) }\end{array}$ & $\begin{array}{l}\text { Volume of saturated } \\
\text { zone }\left(\mathrm{M} \mathrm{m}^{3}\right)\end{array}$ & $\begin{array}{l}\text { Average specific } \\
\text { yield }\end{array}$ & $\begin{array}{l}\text { Total recharge potential as } \\
\text { volume of water }\left(\mathrm{M} \mathrm{m}^{3}\right)\end{array}$ \\
\hline $3-6$ & 14.64 & 1.5 & 21.96 & 0.02 & 0.44 \\
\hline $6-9$ & 134.81 & 4.5 & 606.63 & 0.02 & 12.14 \\
\hline $9-12$ & 22.71 & 7.5 & 170.30 & 0.02 & 3.41 \\
\hline \multirow[t]{2}{*}{$12-15$} & 4.77 & 12 & 57.20 & 0.02 & 1.15 \\
\hline & 176.92 & & & & 17.12 \\
\hline
\end{tabular}

Table 6 Availability of surplus water

\begin{tabular}{llllllr}
\hline Sub-watershed & Area Sq. km & $\begin{array}{l}\text { Monsoon } \\
\text { rainfall }\end{array}$ & Coefficient $(\mathrm{K})$ & $\begin{array}{l}\text { Runoff }(Q=\text { rain- } \\
\text { fall } \times \text { coefficient })(\mathrm{mm})\end{array}$ & $\begin{array}{l}\text { Volume }=(\text { area } \times \text { run- } \\
\text { off })\left(\mathrm{M} \mathrm{m}^{3}\right)\end{array}$ & $\begin{array}{l}30 \% \text { of the total } \\
\text { runoff }\left(\mathrm{M} \mathrm{m}^{3}\right)\end{array}$ \\
\hline SW1 & 55.51 & 1100 & 0.700 & 770.00 & 42.74 & 12.82 \\
SW2 & 41.87 & 1000 & 0.657 & 657.00 & 27.51 & 8.25 \\
SW3 & 41.15 & 960 & 0.685 & 616.50 & 25.37 & 7.61 \\
SW4 & 35.40 & 900 & 0.684 & 615.60 & 21.79 & 6.54 \\
& & & & & 117.41 & 35.22 \\
\hline
\end{tabular}


for recharge, while SW2 in upstream part near Western Ghat region has ample rainfall with high slope having moderate water recharge capacity. The overall attempt of study would be useful for the watershed developer and planner for preparing watershed development plan.

\section{Conclusions}

The present study demonstrates a method to identify groundwater recharge potential zones for water conservation plans and artificial recharge to aquifers, in the semiarid region watershed of Western India. The extension of water resource is done by estimating available recharge space for recharge and sub-watershed wise deficient or surplus surface water availability to conserve in artificial recharge structures. About $24.69 \%$ of the study area has been found to have high groundwater recharge potential, and $24.17 \%$ of the area is moderate for groundwater recharge. Remaining 44.34 and $6.80 \%$ of the total area come under, respectively, low and poor groundwater recharge potential zone. The surplus water availability was calculated based on vadose calculation according to CGWB method. In the watershed, around $17.12 \mathrm{MCM}$ vadose region is present for artificial recharge. So, the water essential for artificial recharge $=17.12 \times 1.33=22.77$ MCM. The total runoff generated from Shivganga River basin is about 117.41 MCM. Area works out to 117.41 MCM, about $30 \%$ of the total runoff, i.e. $35.22 \mathrm{MCM}$ is considered as surplus monsoon runoff available for artificial recharge.

It is clear from the ground investigations that the correctness of GWR potential zone map is genuinely accurate $(82.85 \%)$ and provides valuable inputs for resource management. The higher accuracy is accredited by the use of MCDA analysis. Thus, the use of remote sensing, geospatial and MCDA technologies have demonstrated aptness while identifying the suitable areas for groundwater recharge over other conventional techniques.

\section{Compliance with ethical standards}

Conflict of interest On behalf of all authors, the corresponding author states that there is no conflict of interest.

\section{References}

1. Adimalla N (2018) Groundwater quality for drinking and irrigation purposes and potential health risks assessment: a case study from semi-arid region of South India. Exposure Health. https://doi.org/10.1007/s12403-018-0288-8

2. Kadam AK, Wagh VM, Muley AA, Umrikar BN, Sankhua RN (2019) Prediction of water quality index using artificial neural network and multiple linear regression modeling approach in Shivganga River basin, India. Model Earth Syst Environ 5:1-12

3. Kadam AK, Jaweed TH, Kale SS, Umrikar BN, Sankhua RN (2019) Identification of erosion-prone areas using modified morphometric prioritization method and sediment production rate: $\mathrm{A}$ remote sensing and GIS approach. Geomat Nat Hazards Risk 10(1):986-1006

4. CGWB (2011) Dynamic groundwater resources of India. Central Ground Water Board, Ministry of Water Resources, Government of India, New Delhi

5. Patra S, Mishra P, Mahapatra SC (2017) Delineation of groundwater potential zone for sustainable development: a case study from Ganga Alluvial Plain covering Hooghly district of India using remote sensing, geographic information system and analytic hierarchy process. J Clean Prod 172:2485-2502

6. Rajasekhar M, Raju GS, Raju RS, Basha UI (2018) Data on artificial recharge sites identified by geospatial tools in semi-arid region of Anantapur District, Andhra Pradesh, India. Data Brief 19:1-13. https://doi.org/10.1016/j.dib.2018.04.050

7. Yeh H-F, Cheng Y-S, Lin H-I, Lee C-H (2016) Mapping groundwater recharge potential zone using a GIS approach in Hualianriver, Taiwan. Sustain Environ Res 26(1):33-43

8. Adham A, Sayl KN, Abed R, Abdeladhim MA, Wesseling JG, Riksen M, Fleskens L, Karim U, Ritsema CJ (2018) A GIS-based approach for identifying potential sites for harvesting rainwater in the Western Desert of Iraq. Int Soil Water Conserv Res 6:297-304. https://doi.org/10.1016/j.iswcr.2018.07.003

9. Mishra S, Tiwary D, Ohri A, Agnihotri AK (2019) Impact of municipal solid waste landfilleachate on groundwater quality in Varanasi, India. Groundw Sustain Devt 9(10):1002-1030

10. Senanayake IP, Dissanayake DMDOK, Mayadunna BB, Weerasekera WL (2016) An approach to delineate groundwater recharge potential sites in Ambalantota, Sri Lanka using GIS techniques. Geosci Front 7(1):115-124

11. Magesh NS, Chandrasekar N, Soundranayagam JP (2012) Delineation of groundwater potential zones in Theni district, Tamil Nadu, using remote sensing, GIS and MIF techniques. Geosci Front 3(2):189-196

12. Rajasekhar M, Gadhiraju SR, Kadam A, Bhagat V (2020) Identification of groundwater recharge-based potential rainwater harvesting sites for sustainable development of a semiarid region of southern India using geospatial, AHP, and SCS-CN approach. Arab J Geosci 13(2):24

13. Chenini I, Mammou AB (2010) Groundwater recharge study in arid region: an approach using GIS techniques and numerical modeling. Comput Geosci 36(6):801-817

14. Deepa S, Venkateswaran S, Ayyandurai R, Kannan R, Prabhu MJ (2016) Groundwater recharge potential zones mapping in upper Manimuktha sub basin Vellar River Tamil Nadu India using GIS and remote sensing techniques. Model Earth Syst Environ 2:137

15. Owusu S, Mul ML, Ghansah B, Osei-Owusu PK, Awotwe-Pratt V, Kadyampakeni D (2017) Assessing land suitability for aquifer storage and recharge in northern Ghana using remote sensing and GIS multi-criteria decision analysis technique. Model Earth Syst Environ 3(4):1383-1393

16. Singhai A, Das S, Kadam AK et al (2019) GIS-based multi-criteria approach for identification of rainwater harvesting zones in upper Betwa sub-basin of Madhya Pradesh, India. Environ Dev Sustain 21(2):777-797

17. Jenifer MA, Jha MK (2017) Comparison of Analytic Hierarchy process, Catastrophe and Entropy techniques for evaluating groundwater prospect of hard-rock aquifer systems. J Hydrol (Amst) 548:605-624

18. Mandal U, Sahoo S (2016) Delineation of groundwater potential zones of coastal groundwater basin using multi-criteria 
decision making technique. Water Resour Manag. https://doi. org/10.1007/s11269-016-1421-8

19. Naghibi SA, Pourghasemi HR, Pourtaghi ZS, Rezaei A (2015) Groundwater qanat potential mapping using frequency ratio and Shannon's entropy models in the Moghan watershed, Iran. Earth Sci India 8(1):171-186

20. Naghibi SA, Pourghasemi HR, Pourtaghi ZS, Rezaei A (2015) Groundwater qanat potential mapping using frequency ratio and Shannon's entropy models in the Moghan watershed, Iran. Earth Sci Inf 8:171-186. https://doi.org/10.1007/s1214 5-014-0145-7

21. Singh LK, Jha MK, Chowdary VM (2017) Multi-criteria analysis and GIS modeling for identifying prospective water harvesting and artificial recharge sites for sustainable water supply. J Clean Prod. https://doi.org/10.1016/j.jclepro.2016.11.163

22. Zaidi FK, Nazzal Y, Ahmed I, Naeem M, Jafri MK (2015) Identification of potential artificial groundwater recharge zones in Northwestern Saudi Arabia using GIS and Boolean logic. J Afr Earth Sci 111:156-169. https://doi.org/10.1016/j.jafrearsci.2015.07.008

23. Kaliraj S, Chandrasekar N, Magesh NS (2014) Identification of potential groundwater recharge zones in vaigai upper basin, Tamil Nadu, using GIS-based analytical hierarchical process (AHP) technique. Arab J Geosci 7(4):1385-1401

24. Kadam A, Karnewar AS, Umrikar B, Sankhua RN (2018) Hydrological response-based watershed prioritization in semiarid, basaltic region of western India using frequency ratio, fuzzy logic and AHP method. Environ Dev Sustain 21:1-25

25. Kadam AK, Umrikar BN, Sankhua RN (2018) Assessment of soil loss using revised universal soil loss equation (RUSLE): a remote sensing and GIS approach. Remote Sens Land 2(1):65-75

26. Horton RE (1932) Drainage basin characteristics. Trans Am Geophys Union 13:350-361

27. Bali R, Agarwal K, Nawaz Ali S, Rastogi S, Krishna K (2012) Drainage morphometry of Himalayan Glacio-fluvial basin, India: hydrologic and neotectonic implications. Environ Earth Sci 66(4):1163-1174
28. Shailaja G, Kadam AK, Gupta G, Umrikar BN, Pawar NJ (2019) Integrated geophysical, geospatial and multiple-criteria decision analysis techniques for delineation of groundwater potential zones in a semi-arid hard-rock aquifer in Maharashtra, India. Hydrogeol J 27(2):639-654

29. Kadam AK, Kale SS, Pande NN, Pawar NJ, Sankhua RN (2012) Identifying potential rainwater harvesting sites of a semi-arid, basaltic region of Western India, using SCS-CN method. Water Resour Manag 26(9):2537-2554

30. Umar R, Ahmed I, Alam F (2009) Mapping groundwater vulnerable zones using modified DRASTIC approach of an alluvial aquifer in parts of central Ganga plain, Western Uttar Pradesh. J GeolSoc India 73(2):93-201

31. Kadam AK, Kale SS, Umrikar BN, Sankhua RN, Pawar NJ (2017) Identifying possible locations to construct soil-water conservation structures by using hydro-geological and geospatial analysis. Hydrospatial Anal 1(1):18-27

32. Selvam S, Sivasubramanian P (2012) Groundwater potential zone identification using geoelectrical survey: a case study from Medak district, Andhra Pradesh, India. Int J Geomat Geosci $3(1): 55-62$

33. CGWB (2006) Dynamic groundwater resources of India. Central Ground Water Board, Ministry of Water Resources, Government of India, New Delhi

34. Kumar T, Kant A, Jhariya GDC (2016) Multi-criteria decision analysis for planning and management of groundwater resources in Balod District. Environ Earth Sci, India. https://doi.org/10.1007/ s12665-016-5462-3

Publisher's Note Springer Nature remains neutral with regard to jurisdictional claims in published maps and institutional affiliations. 